\title{
The Effect of Blended Learning Strategy and Creative Thinking of Students on the Results of Learning Information and Communication Technology by Controlling Prior Knowledge
}

\author{
Resien $^{1}$, Harun Sitompul ${ }^{2}$, Julaga Situmorang ${ }^{3}$ \\ ${ }^{1}$ Methodist Private High School, Tanjung Morawa, Indonesia \\ ${ }^{2,3}$ State University of Medan, Indonesia \\ resien.chiu@gmail.com
}

\section{Abstract}

The purpose of this study is to determine the differences in learning outcomes of ICT subjects between groups of students who are taught with blended learning strategies and expository who have the ability to think creatively after being controlled by prior knowledge. This research method uses quasi experiment with $2 \times 2$ factorial design. Data analysis techniques used two-way ANCOVA at a significant level $\square=0.05$. The results showed that (1) ICT learning outcomes between groups of students taught with blended learning strategies were higher than those of students who were taught with expository learning strategies after controlling for prior knowledge; (2) there is an interaction effect between learning strategies and the ability to think creatively on ICT learning outcomes after controlling prior knowledge; (3) for students who have high creative thinking skills, ICT learning outcomes among groups of students taught with blended learning strategies are higher than those of students who are taught with expository learning strategies after controlling prior knowledge; (4) for groups of students who have low creative thinking ability, ICT learning outcomes among groups of students who are taught expository learning strategies are higher than groups of students who are taught with blended learning learning strategies after controlling for prior knowledge. Based on the results of this study, to improve the learning outcomes of Information and Communication Technology students are done by implementing BL learning strategies with regard to student characteristics.
Keywords learning strategies; blended learning; creative thinking; expository; prior knowledge

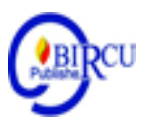

\section{Introduction}

Education is part of the intellectual life of the nation as mandated in the 1945 Constitution, likewise in the Law of the Republic of Indonesia No. 20 of 2003 concerning the National Education System which states that the goal of national education is to educate the life of the nation, to develop the potential of students so that they can become people who have faith and are devoted to God Almighty, noble, capable, creative, independent and 
become citizens of a democratic and responsible country. To that end, the government has sought to develop the education sector in a planned, directed, and gradual manner and integrated with the overall development of the nation's life, both economic, social, cultural, scientific and technological.

Tilaar in his book Education Credits explained that education has two interlocked dimensions. First, education is a human right, which means that people without education cannot realize their humanity. Furthermore, he only becomes human when in a relationship with each other. Secondly, education as a process means that being human does not happen by itself, but is a process of humanity in togetherness with fellow human beings.

The presence of this relatively new ICT, as well as the instability of internet access, limited availability of facilities and infrastructure, the still dominant culture of instructororiented learning, and not all material characters can be studied online into a number of factors underlying the choice of blended learning patterns Effective teachers are those who know how to use computers and how to teach students to use computers to write and be creative. Effective teachers can evaluate the effectiveness of instructional games and computer simulations, know how to use and teach students to use communication tools through computers such as the internet (online learning).

Learning is the process of changing behavior due to interactions among individuals and the environment. Changes in behavior include changes in knowledge, understanding, attitudes, skills, motivation, interests, thinking abilities and so on. Suparman in Sitorus (2019), argues that "learning is a process of behavior change that can be observed by others including by teachers". Dwidayani in Sitorus (2019) states that, "Learning outcomes are measures of success or failure of students after taking teaching and learning activities both in terms of effective, psychomotor, and cognitive which includes knowledge (memory, understanding, application (application)". Learning outcomes are a form of achievement students as well as a symbol of the success of educators in learning students (Yusuf in Sitorus (2019).

According to Sorden technology can open many opportunities for students to learn. But on the other hand teachers still have difficulty using technology effectively. Conceptually blended learning can be one of the learning strategies that teachers can use when teaching. Blended learning combines traditional lecture methods and new methods that are collaborated using technology. Utilization of technology is more appropriate as a medium for achieving better learning outcomes. This unsatisfactory ICT learning outcomes obtained by students may be caused by the learning strategies presented by the teacher which do not attract students' interest and help students understand the problems in ICT. One learning strategy that is considered adaptive to the development of ICT and can increase students' interest and learning independence is a blended learning strategy. Blended learning strategies become part of efforts to use technological advances in improving the quality of learning. Rapid technological advancements have an impact on changes in the world of education and learning, learning technology has adopted and adapted these latest findings in the learning process. 
In the current modern era, the fact is that human dependence, especially students with gadgets, is certainly an initial capital for teachers to be able to develop blended learning strategies in ICT subjects in order to increase students' interest and independence of learning. The addition of learning innovations will arouse the independence and confidence of students who have tried to find and explore learning resources not only from the teacher. Student independence plays an important role in learning success. Sandi states, students who have high independence excel in blended learning that is more student-centered. Therefore, Increasing student independence is a critical one in improving learning outcomes that need to be the attention of teachers and other educational researchers.

This blended learning strategy certainly has its advantages. According to the results of previous studies by Marsh identified the advantages of blended learning, namely: (1) providing a more individual learning experience; (2) providing more personalized learning support; (3) support and encourage students to be able to learn independently and collaborate; (4) increase the involvement of students in learning; (5) accommodate various learning styles of students; (6) providing a place to practice outside of study hours; (7) reducing stress in the learning environment; (8) flexible study time, anytime or anywhere, according to the needs of students; and (9) helping students to develop valuable skills for the 21 st century. In blended learning classes the role of the teacher is very necessary to provide structured and interesting learning in the learning environment of students.

The application of blended learning classes varies according to subjects, grade levels, student characteristics and desired learning outcomes, and also the design of learning based on the student centered learning approach. Blended learning can increase access and flexibility for students, increase active learning, and students can have better experiences and learning outcomes. For teachers, blended learning can improve teaching practices and classroom management. Mixing in blended learning includes: (1) face-to-face and online activities; (2) traditional class schedules in various ways, for example lectures, and or with social media and technology; and (3) simulations, group activities, web-based learning and practice ${ }^{[9]}$. Blended learning that is written offers the opportunity to be both jointly and separately, as well as at the same or different times. Through blended learning a community will be built between the teacher and students who can interact at anytime and anywhere by utilizing learning obtained through computers or from other devices (Android) as a learning tool ${ }^{[10]}$.

The problem now is that it is very rare for a teacher to measure or assess the conditions of creative thinking of each student in supporting the learning process in class. Whereas the mapping of students' creative thinking conditions will later be useful for handling learning strategies for students who have high creative thinking characters and low creative thinking. This is in line with the statement Ervync states that creativity plays an important role in the full cycle of mathematical thinking. In fact, many teachers in primary, secondary and higher education still pay little attention to the creative thinking abilities of their students.

Creative thinking or creativity itself is still an interesting issue among researchers. Designing learning that can give students more opportunities to explore problems that provide many solutions can improve students' abilities in creative thinking. Identifying and 
recognizing students' ability to think creatively can be done by developing assignments or tests of creative thinking. Comparing and making connections between creative thinking abilities and other skills can enrich teachers' insights on the potential or talents of their students. Research on creative thinking on learning outcomes has been previously studied, Kristiana the results of this study explain that there is a significant influence on students' creative thinking abilities on student achievement. In contrast to previous research by Wahyuni and Kurniawan the results of his research explained that there was no significant influence on the ability to think creatively on student learning outcomes. Of course the difference in research results (research gap) on the ability of students to think creatively becomes an interesting study to be discussed and further proven in this study.

Of course, it is not just learning strategies and students' creative thinking abilities that are able to improve student learning outcomes, it turns out there are other things that also need to be examined to measure how much impact the learning strategies of blended learning and creative thinking skills have on student learning outcomes by controlling prior knowledge the student. prior knowledge is the result of knowledge that has been obtained by students before entering higher knowledge. According to Ausubel as quoted by Suparno [20] that the prior knowledge is the knowledge that has been possessed by students before learning takes place which is a prerequisite for following the next learning process. Student prior knowledge is important for teachers to be able to determine the appropriate entry behavior line as a determinant to be able to provide appropriate learning steps.

Research on learning strategies with prior knowledge of learning outcomes has been previously studied by Muawanah the results of this study explain that in groups of students with high prior knowledge, learning outcomes are higher in the experimental class than students in the control class. Furthermore, in the group of students with low prior knowledge, there was no significant difference between students in the experimental class and students in the control class. In contrast to previous studies by Nurfauzia, Kaharuddin and Khaeruddin the results of the study explained that there were significant differences in learning outcomes of students who had high prior knowledge compared to students who had low prior knowledge. Furthermore students who have high prior knowledge do not have significant differences in learning outcomes both taught in the experimental class and in the control class. Then for students who have low prior knowledge, have differences in learning outcomes between students in the experimental class with the control class. Of course the difference in research results (research gap) in this prior knowledge becomes an interesting study to be discussed and further proven in this study.

Based on the problem of unsatisfactory ICT learning outcomes and the relation between the ability to think creatively and the prior knowledge above, the author is interested in conducting experimental research on blended learning strategies that are thought to improve student learning outcomes in ICT. As a comparison of the effects of the implementation of the blended learning strategy, expository learning strategies or direct learning strategies will be used, as well as how it relates to creative thinking (high 
and low) and prior knowledge as a controlling variable in improving ICT learning outcomes for students of Tanjung Morawa Methodist High School, Deli Serdang Regency.

\section{Research Method}

This study uses a quasi-experimental method with treatment design by level 2 x 2 . The research variable consists of one dependent variable, ICT learning outcomes and two independent variables namely learning strategies (blended learning and expository) as treatment variables and creative thinking (high and low) as a moderator / attribute variable. The prior knowledge as a covariate variable.

\section{Result and Discussion}

\subsection{Data Description}

The following is presented in a description of research data which includes, the prior knowledge test score $(\mathrm{X})$ and the ICT learning outcomes of students who became the study sample (Y). The amount to be presented is the number of samples, average score (mean), and standard deviation (standard deviation). Full data summarizing the scores of students' ICT learning outcomes for each group is presented in Table 1.

Table 1. Early Knowledge Score Data and ICT Learning Outcomes Based on Statistical Measures

\begin{tabular}{|c|c|c|c|c|c|c|c|}
\hline \multirow{2}{*}{\multicolumn{2}{|c|}{$\begin{array}{c}\text { Creative } \\
\text { thinking (B) }\end{array}$}} & \multicolumn{4}{|c|}{ Learning strategies (A) } & \multirow{2}{*}{\multicolumn{2}{|c|}{$\sum$}} \\
\hline & & \multicolumn{2}{|c|}{$\mathbf{B L}\left(\mathbf{A}_{1}\right)$} & \multicolumn{2}{|c|}{ Expository $\left(\mathbf{A}_{2}\right)$} & & \\
\hline & & $\mathbf{X i}$ & $\mathbf{Y i}$ & $\mathbf{X i}$ & $\mathbf{Y i}$ & $\mathbf{X i}$ & Yi \\
\hline \multirow{3}{*}{ 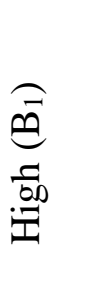 } & $\mathrm{n}$ & 8 & 8 & 8 & 8 & 16 & 16 \\
\hline & $\overline{\bar{X} /}$ & 73.06 & 86.30 & 73.05 & 67.71 & 73.06 & 77.01 \\
\hline & $\mathrm{S}$ & 10.54 & 7.47 & 10.29 & 9.09 & 10.06 & 12.52 \\
\hline \multirow{3}{*}{ 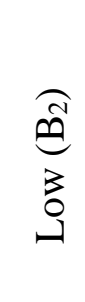 } & $\mathrm{n}$ & 8 & 8 & 8 & 8 & 16 & 16 \\
\hline & $\begin{array}{c}\overline{\bar{X} /} \\
\bar{Y}\end{array}$ & 69.14 & 66.04 & 68.38 & 74.08 & 68.76 & 70.06 \\
\hline & $\mathrm{S}$ & 9.51 & 6.68 & 12.86 & 8.55 & 10.94 & 8.49 \\
\hline
\end{tabular}




\begin{tabular}{|c|c|c|c|c|c|l|l|}
\hline \multirow{5}{*}{$\sum$} & $\mathrm{n}$ & 16 & 16 & 16 & 16 & & \\
\cline { 2 - 8 } & $\bar{X} /$ & 71.10 & 76.17 & 70.71 & 70.89 & & \\
\cline { 2 - 8 } & $\mathrm{S}$ & 9.91 & 12.50 & 11.51 & 9.14 & & \\
\hline
\end{tabular}

Information :

$\mathrm{X}$ : Preliminary Knowledge

Y: ICT Learning Outcomes

$\mathrm{n}$ : Number of students in each group

$X X$ : Average value of prior knowledge (covariate variable

$Y Y$ : Average value of ICT learning outcomes (dependent variable)

\subsection{Hypothesis test}

Hypothesis testing in this study is related to the main effect (main effect) of independent variables, namely the BL learning strategy and expository learning strategy. In addition, hypothesis testing is also related to interaction effect, namely the presence or absence of interaction between learning strategies and the ability to think creatively on ICT learning outcomes. The analytical technique used in testing research hypotheses is the 2way ANKOVA Test. The results of calculations with ANKOVA are presented in Table 2.

Table 2. Summary of Hypothesis Tests with ANKOVA

\begin{tabular}{|l|r|r|r|r|r|}
\hline Sumber Varians & Jkyres & \multicolumn{1}{l|}{ db } & \multicolumn{1}{l|}{ RJKyres } & \multicolumn{1}{c|}{ Fo } & F-table \\
\hline Among A & 204.98 & 1 & 204.98 & $\mathbf{6 . 5 8 8}$ & 4.210 \\
\hline Among B & 164.27 & 1 & 164.27 & $\mathbf{5 . 2 8 0}$ & 4.210 \\
\hline Interaction AxB & 1463.87 & 1 & 1463.87 & $\mathbf{4 7 . 0 4 8}$ & 4.210 \\
\hline PA (X) & 955.08 & 1 & 955.08 & $\mathbf{3 0 . 6 9 6}$ & 4.210 \\
\hline inside & 840.09 & 27 & 31.11 & $\mathbf{-}$ & - \\
\hline Total & 2673.22 & 30 & - & - & - \\
\hline
\end{tabular}

Information :

** : very significant $\left(\mathrm{F}_{\text {count }}<\mathrm{F}_{\text {table }}\right.$ on alpha

$0.05)$ ts $\quad$ : not significant $\left(\mathrm{F}_{\text {count }}<\mathrm{F}_{\text {table }}\right)$

$\mathrm{db} \quad$ : Free degree 
$\mathrm{JK}_{\text {res }} \quad$ : Number of residual squares

$\mathrm{RJK}_{\mathrm{res}}$ : Average number of residual squares

3.3 Differences in ICT Learning Outcomes between Students Using BL Learning Strategies and Expository Learning Strategies, After Controlling for prior knowledge (Main Effect)

ANAKOVA calculation results show that Fcount $=6.588>$ from Ftable $(\alpha=0.05)$ $(1.27)=4.21$, the null hypothesis is rejected and $\mathrm{Ha}$ is accepted or there are differences in ICT learning outcomes between students taught with BL learning strategies and strategies expository learning. Thus, the learning strategy influences students' ICT learning outcomes after controlling for prior knowledge.

Furthermore, the acquisition of the average value of the learning outcomes of groups of students taught with learning strategies of BL 76.07 and groups of students taught with expository learning strategies of 71.01. It is seen that the learning outcomes of groups of students taught with BL learning strategies are greater than the learning outcomes of students taught with expository learning strategies. This means that BL learning strategies are proven to have a more effective influence on student ICT learning outcomes so that it can be concluded that ICT learning outcomes of students who use BL learning strategies are higher than students who use expository learning strategies. Thus, the research hypothesis which states that there is a difference between students' ICT learning outcomes who are taught using the BL learning strategy and the expository learning strategy after controlling the student's prior knowledge is verified.

3.4 the interaction between learning strategies and The Ability to Think Creatively on ICT Learning Outcomes, After Controlling for prior knowledge (Interaction Effect)

The results of testing the first hypothesis indicate that there are differences in ICT learning outcomes between students using BL learning strategies and expository learning strategies. This research has proven that ICT learning outcomes of students who use BL learning strategies are higher than students who use expository learning strategies after controlling prior knowledge.

Based on the ANKOVA calculation results (Table 4.14) on the source of the interaction variance A X B shows that the price of Fcount $=47.048<$ of Ftable $(\alpha=0.05)$ $(1.27)=4.21$, then $\mathrm{HO}$ is rejected and $\mathrm{Ha}$ is accepted. This means that learning strategies have an influence on ICT learning outcomes depending on the ability to think creatively after controlling prior knowledge, and vice versa. Thus the research hypothesis which states that there is an interaction between learning strategies with the ability to think creatively on ICT learning outcomes after controlling for prior knowledge is verified.

In the form of graphic interaction between the learning approach with the ability to think creatively on ICT learning outcomes can be seen in Figure 1. 


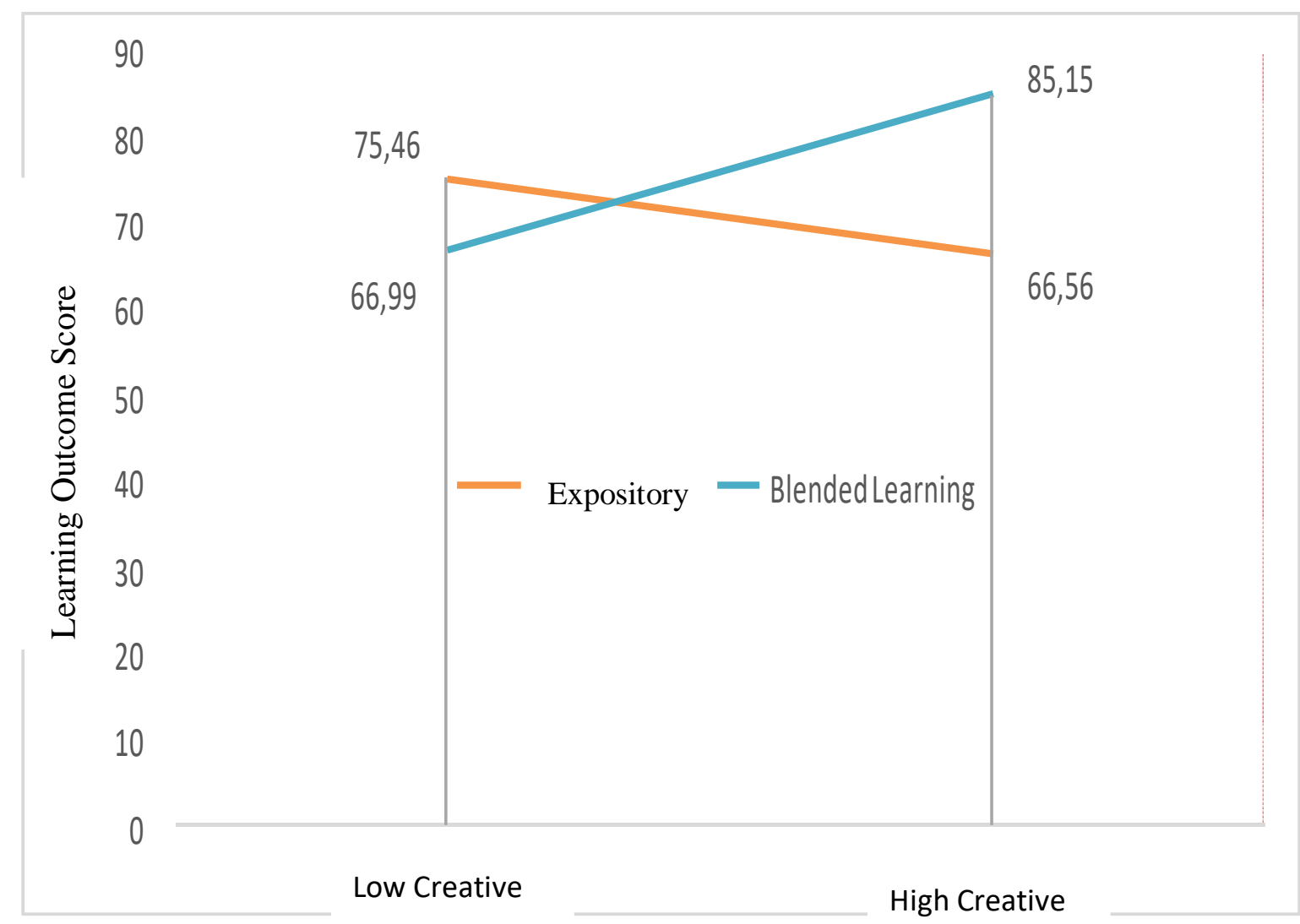

Figure 2. Graph of interaction of learning strategies and creative thinking abilities on ICT learning outcomes after controlling prior knowledge

3.4 Differences in ICT Learning Outcomes of Students Who Use BL Learning Strategies and Expository Learning Strategies, on Students Who Have High Creative Thinking Skills After Controlling prior knowledge (Simple Effect)

The results of further tests with the Tukey test in Table 4.15 show that the comparison of ICT learning outcomes of students who use BL learning strategies and expository learning strategies for students who have high creative thinking abilities is obtained by calculating $\mathrm{Q}$ count $=9.43 \mathrm{Q}_{\text {table }}(\alpha=0.05)(3,8)=4.04$, then H0 is rejected and $\mathrm{Ha}$ is accepted. Thus it can be said that the ICT learning outcomes of students who use BL learning strategies are higher than the value of student learning outcomes using expository learning strategies in students who have high creative thinking abilities after controlling prior knowledge.

Based on the average residual test results (Table 4.16), values of 85.15> 66.56 were obtained. This shows that the ICT learning outcomes of students who are taught using BL learning strategies are higher than the learning outcomes of students who are taught with expository learning strategies in students who have high creative thinking abilities. This result also shows that students who have high creative thinking ability are very apt to apply BL learning strategies. Thus it can be concluded that the results of students' ICT learning 
taught with BL learning strategies are better than the learning outcomes of students taught by using expository learning strategies, for students who have a tendency for high creative thinking abilities after controlling prior knowledge.

Furthermore, research hypotheses which state that ICT learning outcomes of students who use BL learning strategies are higher than students who use expository learning strategies in students who have high creative thinking abilities after controlling for their original knowledge are tested.

\subsection{Differences in ICT Learning Outcomes of Students Who Use BL Learning Strategies and Expository Learning, on Students Who Have Low Creative Thinking Skills After Controlling prior knowledge (Simple Effect)}

Based on the results of further tests with the Tukey test in Table 4.15 it is known that the comparison of ICT learning outcomes of students who are taught using BL learning strategies and expository learning in students who have low creative thinking abilities is obtained Qcount $=4.3>$ Qtable $(\alpha=0.05)(3.8)=4.04$, then H0 is rejected and $\mathrm{Ha}$ is accepted. Thus it can be concluded that there are differences in ICT learning outcomes of students who use esoteric learning strategies are higher than students who use BL learning strategies in students who have low creative thinking skills after controlling prior knowledge.

Based on the average residual test results (Table 4.16), values> 75.46> 66.99 are obtained. This shows that the ICT learning outcomes of students with low creative thinking skills taught using expository learning strategies tend to be higher than the learning outcomes of students with low creative thinking abilities who are taught with BL learning strategies. Furthermore, the research hypothesis which states that ICT learning outcomes of students who have low creative thinking abilities tendency in the class of expository learning strategies is higher than students who have low creative thinking abilities in students who are taught with BL learning strategies after controlling for prior knowledge of the truth.

The first hypothesis testing shows that there is a significant difference in influence between BL learning strategies and expository learning strategies. This research has proven that students' ICT learning outcomes who are taught with BL learning strategies are higher than students who are taught with expository learning strategies after controlling prior knowledge.

Proving hypotheses based on empirical studies conducted by researchers is supported by theories and concepts put forward by experts as stated by Bersin that BL learning strategies are a combination of various training media (technology, activities, and types of events) to create optimal training programs for a certain audience. The term "blended" comes from the concept that teachers teach in the traditional way with other electronic media formats. Successful learning will certainly improve and improve the quality of learning. In learning BL students independently learn the material that has been given by the teacher according to the topic face to face or online. The combination of face-to-face 
learning and online or BL will give students more freedom to determine their learning speed.

The results of Precel, Alkalai and Alberton's research [29] related to the contribution of components in BL learning show that learning components that are considered to contribute the most to learning are tasks (mean $=4.72)$, printed books $($ mean $=4.54)$, meeting presentations (mean $=4.42$ ), and face-to-face lectures with instructors (mean = 4.15). Online video contributed to learning (mean $=3.83)$, e-book lessons $($ mean $=3.32)$, although the contribution was low, almost half of the participants $(46.5 \%)$ stated using it frequently.

Another theory that is in line with this research is the opinion of Christensen, Horn and Staker saying the BL learning strategy is a formal education program in which a student learns at least in part through online learning with some elements of student control over time, place, path, and / or speed and at least part of it is in traditional locations that are watched far from home. Facilities along each student's learning path in the course or in connected subjects to provide an integrated learning experience.

The research results of the researchers were also proven by the researchers who stated the benefits of the BL strategy including success in: a) achieving learning objectives; b) changing learning patterns that were previously teacher-centered to studentcentered; c) balancing student independence in learning, and d) motivating students to discipline themselves in learning.

Another theory similar to the results of this study was also put forward by Shand and Farrelly that online learning programs and BL enable teachers to reap the benefits by giving more individual attention to students who need greater learning assistance.

Through BL learning strategies especially the use of internet media or web-based technology in learning (online learning) using LMS Edmodo students have wider opportunities to understand what is learned by developing their thinking skills and not just making teachers as the only source of learning or information . In addition, BL learning can train students to be more independent in developing creativity in learning with sufficient exercises and to do assignments with more enthusiasm through interesting presentations. Students in BL learning are directed and invited to be able to construct their own learning material with the help of online technology that is utilized. In learning BL the involvement of students can be actively monitored by the teacher, so students will increasingly understand the subjects of Information and Communication Technology so as to produce better learning outcomes.

The second hypothesis shows that there is an interaction effect between learning strategies and creative thinking. Based on the results of testing with Anakova, the null

hypothesis is rejected. Thus, the research hypothesis which states that ICT learning outcomes of students who have the ability to think creatively after controlling prior knowledge, and vice versa, the ability to think creatively (high / low) influences students' ICT learning outcomes depending on learning strategies after controlling prior knowledge.

The results of this study indicate an interaction between the selection of learning strategies and the ability to think creatively. To improve ICT learning outcomes of students who have high creative thinking abilities, they are better suited to be taught with 
BL learning strategies, while for students who have low creative thinking abilities are more suitable to be taught with expository learning strategies.

Learning strategy is a set of learning materials and procedures that are used together to produce learning outcomes for students. In accordance with the above view, it can be explained that the learning strategy is a condition designed by the teacher so that students can be facilitated to achieve the learning objectives that have been set. So the learning strategy is planned efforts in manipulating learning resources so that the learning process occurs within the students.

Learning independence BL can train students to be more independent in developing creativity in learning with sufficient exercises and to do assignments with more enthusiasm through an interesting presentation. Students in BL learning are directed and invited to be able to construct their own learning material with the help of online technology that is utilized. In learning BL the involvement of students can be actively monitored by the teacher, so students will increasingly understand the subjects of Information and Communication Technology so as to produce better learning outcomes. Bostrom and Lassen in their research results said that teaching based on individual learning styles is an effective way to ensure student achievement and motivation. Awareness of learning styles, it is said, influences meta-cognition and the choice of relevant learning strategies. Awareness of self-improvement will give students a new perspective on their learning potential. Such positive academic experiences can increase student confidence.

The accuracy in choosing approaches, strategies, and learning methods that are appropriate can provide clear direction to the teaching process. In addition, the teacher can design and set general rules or principles so that learning runs as desired. Likewise with the learning conditions, especially the internal conditions of students, in this case students' thinking styles can also determine their learning outcomes. This is in line with research conducted by Shi entitled "A Study of the Relationship between Cognitive Styles and Learning Strategies" which concluded that there is a significant influence between thinking styles with learning strategies.

The third hypothesis shows that ICT learning outcomes taught with BL learning strategies with higher creative thinking abilities are higher than students taught with expository learning strategies after controlling for prior knowledge. Thus learning with the BL learning strategy carried out in this study can improve the learning outcomes of Information and Communication Technology higher than the Expository learning strategy for students who have high creative thinking after controlling prior knowledge. This finding answers the hypothesis that the learning outcomes of information and communication technology students who are taught with BL learning strategies are higher than students who are taught with expository learning strategies for students who have high creative thinking after controlling prior knowledge.

Heller said many observers argued that there was no substitute for face-to-face contact, regardless of the extent to which technology had developed. For example, face-toface contact facilitates the transfer of tacit knowledge or knowledge that is not written or cannot be defined, but is obtained through experience. When communicating face to face, the speaker can use visual cues from the audience to get fast and fast feedback and make 
quick adjustments as needed. Visual cues and social presence in face-to-face dialogue also allow members to more easily learn about each other's background, skills, experience, and area of expertise. These cues build trust in groups that interact face to face. Although organizing and planning for face-to-face contact can be difficult and expensive, this in itself can send valuable messages to recipients.

\section{Conclusion}

Based on the results of the study conclusions can be drawn as follows. (1) ICT learning outcomes among groups of students who are taught with BL learning strategies are higher than groups of students who are taught with expository learning strategies after controlling prior knowledge; (2) There is an interaction effect between learning strategies and students' creative thinking abilities on ICT learning outcomes after controlling prior knowledge. If the students we teach in ICT subjects have high creativity thinking we should implement a BL learning strategy. If the students we teach have low creative thinking the teacher should apply expository learning strategies; (3) For groups of students who have high creative thinking abilities, ICT learning outcomes between groups of students taught with BL learning strategies are different from groups of students who are taught with expository learning strategies after controlling prior knowledge; and (4) For groups of students who have low creative thinking skills, ICT learning outcomes among groups of students who are taught expository learning strategies are higher than groups of students who are taught with BL learning strategies after controlling for prior knowledge.

\section{References}

Anwar, N., Muhammad, Aness, Muhammad, Khizar, et.al. (2012). Relationship of Creative Thinking with the Academic Achievements of Secondary SchoolStudents. International Interdisciplinary Journal of Education. 1(3). Hlm. 44-47

Ai, X. (1999). Creativity and Academic Achievement: An Investigation of Gender Differences. Creativity Research Journal, 12(4), Hlm.329-337.

Asian Journal of Psychology and Education, 6. Hlm.1-4.

Azhar, Arsyad. (2002). Media Pembelajaran. Jakarta : Raja Grafindo Persada, 2002.

Bersin, Josh. (2004). The Blended Learning Book : Best Practice, Proven Methologies, and Lessons Learned. United State of America : Pfeifer. Hlm.xv, 56.

Asha, C. B. (1980). Creativity and academic achievement among secondary school children.

Bonk, Curtis, J \& Graham, R., Charles. 2006. The Handbook of Blended Learning : Global Perspective, Local Designs. San Fransisco : Pfeiffer. Hlm. 4-5.

Bostrom, Lena, \& Lassen, M., Liv. (2006). Unraveling Learning, Learning Styles, Learning 
Strategies and Metacognition. Creative Problem Solving Ability". Journal of the Korea Society of Mathematical Education Series D: Research in Mathematical Education, Vol. 7(3)

Christensen, Clayton, M., Horn, Michael, B., \& Staaker, Heater. (2013). Is K-12 Blended

Learning Disruptive? An Introduction to the Theory of Hybrids. Clayton Christensen Institute for Disruptive Innovation. Hlm.9.

De Bono, E. (2007). Revolusi Berpikir. Bandung:Kaifa. Ismienar, S., Andrianti, H., \& A., S. V. 2009. Thinking. Malang.

Dick, Walter; Carey, Lou; dan Carey, James O. (2009). The Systematic Design of Instructiona. New Jersey : Pearson Education, Inc. Hlm. 7, 70, 93

Dwiyogo, D., Wasis. (2018). Pembelajaran Berbasis Blended Learning. Depok : PT. RajaGrafindo Persada. Hlm.133,135.

Ervync, G. (1991). "Mathematical Creativity”. Dalam Tall, D. Advanced Mathematical Learning. London: Kluwer Academic Publisher

Garisson, Randy, D and Vaughan, Norman, D. (2008). Blended Learning in Higher Education. United States of America : John Wiley \& Sons, Icn.

Getzels, J. W. and Jackson P. W. (1962). Creativity and intelligence: Explorations with gifted

students. New York: Wiley.

Haylock, D. (1997). "Recognising mathematical creativity in school children". Zentralblatt fuer Didaktikder Mathematik, Vol. 29(3)

Kristiana, Melia. (2016). Pengaruh Kemampuan Berpikir Kreatif Dan Positif Terhadap Prestasi Belajar Matematika. JKPM, Vol.02, No.01, 01 Des 2016. Hlm. 57-68.

Lee, K. S., Hwang, D. J. Seo, J. J. (2003). “A Development of the Test for Mathematical Mahmudi, A. (2010). "Mengukur Kemampuan Berpikir Kreatif Matematis". Makalah. Konferensi Nasional Matematika XV UNIMA 30 Juni - 3 Juli 2010.

Mann, E. (2005). "Mathematical Creativity and School Mathematics: Indicators of Mathematical Creativity in Middle School Students". Disertasi. University of Connecticut.

Marsh, Debra. (2012). Blended Learning : Creating Learning Opportunites for Languages Learners. The United States of America : Cambridge University Press, hlm. 4 Learning and Teaching Unit 2013, Fundamentals of Blended Learning. Australia : University of Western Sydney, 2013. Hlm. 5.

Muawanah, S. (2017). Pengaruh Strategi Pembelajaran dan Pengetahuan Awal TerhadapHasil

Belajar Teknik Listrik Dasar Otomotif Siswa SMKN 1 Kota Bekasi. Jurnal Teknologi Pendidikan. Vol. 19, No. 2, Agustus 2017.

Nurfauzia, Kaharuddin dan Khaeruddin. (2018). Pengaruh Model Pembelajaran Penemuan 1

Dan Pengetahuan Awal Terhadap Hasil Belajar Fisika Peserta Didik Kelas XI MIA SMAN 16 Makassar. Tesis. Makasar : Universitas Negeri Makasar.

Prawiradilaga, Dewi Salma. (2007). Prinsip Desain Pembelajaran. Jakarta : Kencana, hlm.24. 
Santrock, John W. 2008. Psikologi Pendidikan Edisi Kedua, terjemahan Tri Wibowo B.S.. Jakarta : Kencana Perdana Media Group. Hlm. 357 \& 638.

Precel, Karen, Alkahalai, Yoram \& Alberton, Yael. (2009). Pedagogical and Design Aspects of a Blended Learning Course. International Review of Research in Open Distance Learning. Volumne 10, Number 2. ISSN: 1492-3831.

Purwaningsih, Helen. (2014). Pengaruh Blended Learning dan Gaya Belajar Terhadap Hasil

Belajar IPA. Jurnal Teknologi Pendidikan. 16(2). Hlm.100.

Reigeluth, C. M., \& Joseph, R. (2002). Beyond Technology Integration : The Case for Technology Transformation. Educational Technology, 42(4). Hlm.9-14 West,R.E., \& Graham, C. R. (2005). Five Powerful Ways Technology Can Enhance Teaching and Learning in Higher Education. Educational Technology, 45(3). Hlm.20-27.

Runco, M. A. (2007). Creativity. Theories and Themes: Research, Development and Practice.

Amsterdam: Elsevier.

Sandi, Gede. (2012). Pengaruh Blended Learning Terhadap Hasil Belajar KimiaDitinjau Dari

Kemandirian Siswa. Jurnal Pendidikan dan Pengajaran, Jilid 45, Nomor 3, Oktober 2012. Shand, Kristen \& Farrelly, Glassett, Susan. (2017). Using Blended Teaching to Teach

Blended Learning : Lessons Learned from Pre-Service Teachers in a Instructional Methods Course. Journal of Online Learning Research. 3(1). Hlm.9.

Shi, Changju. (2011). Study of the Relationship Between Cognitive Styles and Learning Strategies. Higher Education Studies. 1(1). Hlm.20-26.

Silver, E. A. (1997). "Fostering Creativity through Instruction Rich in Mathematical Problem Solving and Problem Posing”. The International Journal on Mathematics Education, Vol.29(3).

Sorden, Stephen, D. (2011). Relationships Among Collaborative Learning, Social Presence and Student Satisfaction In a Blended Learning Environment. Northern Arizona University. Disertation. Hlm.16,17.

Siswono, T. Y. E. (2004). "Identifying Creative Thinking Process of Students Through Mathematics Problem Posing”. Makalah. International Conference on Statistics and Mathematics and Its Application in the Development of Science and Technology, Universitas Islam Bandung, 4-6 Oktober 2004.

Sitorus, H. (2019). The Effect of Learning Strategy and Thinking Ability on The Students' Learning Outcomes in Economics Subject of XI Social Students in Senior High School State 1 in Pematang Siantar. Budapest International Research and Critics in Linguistics and Education (BirLE) Journal. p. 451-460.

Suparno, Paul. (1997). Teori-Teori Belajar. Jakarta : Erlangga. Hlm.53-54. Seels, Barbara; dan Glasgow, Zita. 1998. Making Instructional Design Decision 2nd Edition. New Jersey : Prentice Hall, Inc. Hlm.275

Tilaar, H.A.R., Paat, Jimmy, Ph., \& Paat, Lody. (2011). Pedagogik Kritis. Jakarta : Rineka Cipta. Hlm.13.

Torrance, E. P. (1959). Explorations in Creative Thinking in the Early School Year: VI. 
Highly Intelligent and Highly Creative Children in a Laboratory School. Minneapolis: Bur. Edu. Res. University of Minnesota.

Uno, B., Hamzah, Umar K; dan Panjaitan, Masri, K. (2014). Variabel Penelitian Dalam Pendidikan Pembelajaran. Jakarta : PT. Ina Publikatama. Hlm. 113-115.

Wahyuni, Arie dan Kurniawan, Prihadi. (2018). Hubungan Kemampuan Berpikir Kreatif Terhadap Hasil Belajar Mahasiswa. Jurnal Matematika Vol. 17, No. 2 